\title{
Influence of chromium supplementation on energy metabolism in horses used in policing activity
}

\author{
[Influência da suplementação com cromo sobre o metabolism energético em equinos \\ usados em atividade de policiamento] \\ L.A. Fonseca ${ }^{1}$, F.M. Girardi ${ }^{1}$, C.S. Coelho ${ }^{2}$, G. Barioni ${ }^{1}$, V.B. Rangel ${ }^{1}$, R.C. Gonçalves ${ }^{3}$ \\ ${ }^{1}$ Faculdade de Medicina Veterinária, Centro Universitário Vila Velha (UVV) \\ Rua Comissário José Dantas de Melo, 21 \\ 29102-770 - Vila Velha, ES \\ ${ }^{2}$ Aluna de pós-graduação - Faculdade de Medicina Veterinária e Zootecnia - Centro Universitário Vila Velha, ES \\ ${ }^{3}$ Faculdade de Medicina Veterinária - UNESP - Campus Botucatu, SP
}

\begin{abstract}
The influence of chromium supplementation on some blood variables in 11 adult stallions used for policing activities was evaluated. Each animal was treated with $11 \mathrm{mg}$ of chromium $/ 400 \mathrm{~kg}$ body weight, orally, for a period of 30 days. On days 0 (before) and 30 (after) the animals were evaluated and blood samples were obtained before and after exercise. Plasma glucose and lactate and serum cortisol and insulin were analyzed in each of these moments. On day 0 , plasma glucose concentrations were $68.4 \pm 5.6 \mathrm{mg} / \mathrm{dL}$ and $78.7 \pm 6.5 \mathrm{mg} / \mathrm{dL}$; plasma lactate concentrations were $6.2 \pm 0.6 \mathrm{mg} / \mathrm{dL}$ and $13.1 \pm 7.6 \mathrm{mg} / \mathrm{dL}$; serum cortisol values were $48.5 \pm 7.9 \mathrm{ng} / \mathrm{mL}$ and $42.6 \pm 19.7 \mathrm{ng} / \mathrm{mL}$; and serum insulin values were $3.0 \pm 6.4 \mu \mathrm{UI} / \mathrm{mL}$ and $1.9 \pm 1.7 \mu \mathrm{UI} / \mathrm{mL}$, respectively, before and after exercise. On day 30, plasma glucose concentrations were $73.3 \pm 5.7 \mathrm{mg} / \mathrm{dL}$ and $78.4 \pm 6.7 \mathrm{mg} / \mathrm{dL}$; plasma lactate concentrations were $7.3 \pm 0.9 \mathrm{mg} / \mathrm{dL}$ and $7.6 \pm 1.2 \mathrm{mg} / \mathrm{dL}$; serum cortisol values were $62.9 \pm 21.8 \mathrm{ng} / \mathrm{mL}$ and $40.3 \pm 17.0 \mathrm{ng} / \mathrm{mL}$; and serum insulin values were $1.4 \pm 1.3 \mu \mathrm{UI} / \mathrm{mL}$ and $1.7 \pm 1.4 \mu \mathrm{UI} / \mathrm{mL}$, respectively, before and after exercise. As an effect of the exercise, a decrease was shown in the concentration of serum insulin and an increase in plasma lactate and glucose. Chromium supplementation resulted in a reduction of lactate values after physical activity, possibly indicating that chromium contributed to a better utilization of plasma glucose and to a better adaptation of animals to physical activity.
\end{abstract}

Keywords: equine, biochemistry, chromium, exercise

\section{RESUMO}

O presente trabalho avaliou a influência da suplementação com cromo em algumas variáveis sanguíneas em 11 equinos machos, adultos, usados em atividade de policiamento. Cada animal recebeu $11 \mathrm{mg}$ de cromo/400kg de peso corpóreo, via oral, durante 30 dias. Nos dias 0 (antes) e 30 (após), os animais foram avaliados e amostras de sangue foram obtidas antes e após o exercício. Glicose e lactato plasmáticos e cortisol e insulina séricas foram determinados. No dia 0 , as concentrações de glicose plasmática foram 68,4 $\pm 5,6 \mathrm{mg} / \mathrm{dL} e$

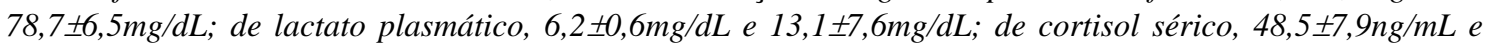

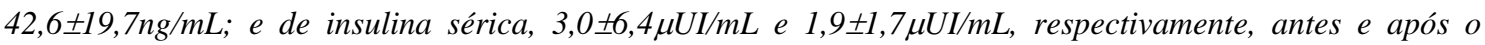

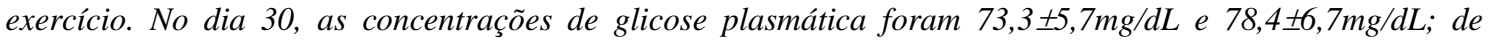

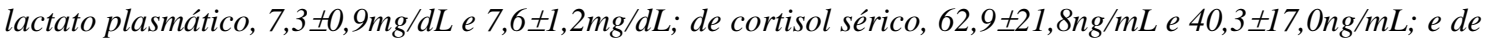

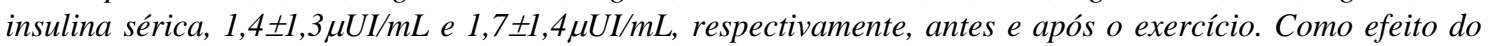
exercício, foi demonstrado redução na concentração sérica de insulina e aumento no lactato e glicose plasmáticas. A suplementação com cromo resultou em redução dos valores de lactato após a atividade física, possivelmente indicando que o cromo contribuiu para a melhor utilização da glicose plasmática e melhor adaptação ao exercício físico realizado.

Palavras-chave: equino, bioquímica, cromo, exercício

Recebido em 5 de julho de 2010

Aceito em 10 de agosto de 2011

Email: leandro.abreu@uvv.br 


\section{INTRODUCTION}

Exercise can be defined as a "normal stress, acting as a stimulator of vital functions" (Booth and Thomason, 1991). According to Leal et al. (2007), animals undergo changes in their cortisol concentration in order to adapt to chronic physical stress. Its main function is to maintain blood glucose in higher levels during fasting or exercise (Kaneko, 1997). This demonstrates the interdependence between this hormone and glucose regulation (Teixeira-Neto et al., 2007).

The synthesis and usage of appropriate energy are essential for horses used in races and have a critical function for its optimal performance (Harris and Harris, 1998). Glucose is an essential source of energy for muscular activity and the energy can be produced aerobically, usually in prolonged exercise, or anaerobically, usually in high intensity exercises (Trilk, 2002; TeixeiraNeto et al., 2007). The more intense the exercise, the more lactate and $\mathrm{H}^{+}$will be synthesized, providing energy in a fast way by anaerobic glycolysis (McGowan, 2008). There is a positive correlation between lactate concentration after physical activity and competitive performance of the animal (Lindner, 2000).

The main effect of insulin on carbohydrate metabolism is to enable the transport of glucose across the cell membrane. Also, it stimulates lipogenesis and hepatic synthesis of glycogen (Reece, 2008). According to McKeever (2002), the insulin response to intense exercise is well documented on horses; like humans and other species, it has low insulin concentration during physical activity mainly because cortisol and cathecolamines are in action. A lower concentration of insulin enables an increased gluconeogenesis in order to maintain blood glucose in higher concentrations during exercise. The suppression of insulin and a resulting higher glucose concentration in the blood prevent the emergence of central mechanisms of fatigue (McKeever, 2002).

Chromium can affect the metabolism of carbohydrates, lipids and the absorption and metabolism of proteins and is essential to increase insulin sensitivity and glucose uptake. When used in food, it shows satisfactory results in relation to carbohydrate metabolism in working horses (Ott and Kivipelto, 1999).
Pagan et al. (1995) related that chromium supplementation reduces plasma glucose and the time required for the glucose levels to return to baseline values in working horses. Chromium may also lower concentrations of blood glucose throughout the day. It is hoped that the supplementation increases the availability of glucose to muscle tissue, thereby reducing the production of lactate for an exercise of the same level.

The aim of this study was to evaluate the influence of chromium supplementation on energy metabolism in horses submitted to the activity of urban policing.

\section{MATERIAL AND METHODS}

Eleven male horses of Brasileiro de Hipismo breed, ages between 10 and 20 years, were used in the experiment. In terms of housing, feeding and hygienic management, all animals were kept under similar conditions. The animals received daily Tifton sp. hay ad libitum followed by a commercial diet $(1.2 \mathrm{~kg} / 100 \mathrm{~kg}$ of BW - Royal Horse SPORT - Socil Evialis Nutrition Animal; containing undetermined concentration of chromium) supplemented with $100 \mathrm{~g}$ of inorganic mineral (Tortuga Zootécnica Land Company Ltda.).

Age, weight, general health, attitude, appearance of mucous membranes and physiological parameters of each animal were recorded. The animals were considered healthy on physical examination, and according to the parameters suggested by Radostits et al. (2002).

All horses selected for the experiment were used to the policing activity imposed and they had been practicing it for at least six months prior to the experiment. Animals left the stables for workout in the morning and had a working shift of eight hours per day. The type of exercise was classified as moderate - low intensity and long duration - in which the horses switched periods of trot and walk. All horses were submitted to the same type of exercises and went for the workout in the same group, before and after supplementation.

Four blood samples were taken of each animal. Two were taken before the period 
supplementation and these were considered the control values as the animals were used to the type and duration of exercise. M1 was obtained at rest in individual stalls, after animals fasted for eight hours, right before the beginning of the supplementation period. M2 was obtained immediately after eight hours of exercise, and also before the beginning of supplementation. A dosage of $11 \mathrm{mg}$ of chromium/400kg of body weight was orally added for 30 days. These dosages were higher than the guidelines of Pagan et al. (1993), who recommend 5mg/day. The National Research Council (Nutrient..., 2007) does not have a specific recommendation for chromium (sport horses). M1S was obtained at rest in individual stalls, after the animals fasted for eight hours, after these 30 days of supplementation and M2S was obtained immediately after eight hours of exercise, after 30 days of supplementation. During the 30 days of supplementation no horses had health problems.

Blood samples were obtained after local antisepsis from the $V$. jugularis externa with disposable needles for multiple samples $(25 \mathrm{~mm} x$ $0.8 \mathrm{~mm}$ ), using a vacuum system (Vacutainer $($ ) $)$. For the determination of plasma lactate and glucose, glass tubes containing fluoride sodium were used. For the determination of serum cortisol and insulin, siliconized glass tubes without anticoagulants were used. The concentration of plasma glucose was determined as suggested by Schmid and Forstner (1986). The lactate concentration was determined as suggested by Pryce (1969). Analyses were performed in a semi-automatic biochemical analyzer (BioPlus 2000, Quimis Scientific Instruments Ltd, Diadema, SP, Brazil) according to the manual of the commercially available kit (Bioclin - Quibasa, Basic Chemistry, Belo Horizonte, MG, Brazil) in the Laboratório Clínico Veterinário do Centro Universitário Vila Velha. The determination of serum cortisol and insulin was performed in the BET Laboratories, Rio de Janeiro, RJ, using the technique of solid phase radioimmunoassay (Gamma Count Cobra 2 - DPC MedLab - Sao Paulo, SP, Brazil) and commercially available kits (DPC MedLab - São Paulo, SP, Brazil) according to the manual. All tests were performed twice, following the suggestions of Freestone et al. (1991).

The gathered data was analysed using the program SAEG (SAEG/UFV, 2007). The analysis of variance at $5 \%$ probability was used to identify possible differences between the variances of the treatments, and the Student ttest, also at $5 \%$ probability, to detect differences between the treatments.

\section{RESULTS AND DISCUSSION}

The results of biochemical and hormonal analysis are depicted as mean \pm standard deviation on Table 1. Biochemical analysis before supplementation with chromium showed significant difference between M1 and M2 for all variables evaluated, except for cortisol.

Table 1. Results of biochemical and hormonal parameters before and after supplementation with chromium in horses submitted to physical exercise

\begin{tabular}{lcccc} 
& \multicolumn{2}{c}{ Before supplementation } & \multicolumn{2}{c}{ After supplementation } \\
\cline { 2 - 5 } Parameter & M1 & M2 & M1S & M2S \\
\hline Glucose $(\mathrm{mg} / \mathrm{dL})$ & $68.6 \pm 5.6 \mathrm{a}^{*}$ & $78.7 \pm 6.5 \mathrm{~b}$ & $73.3 \pm 5.7 \mathrm{a}$ & $78.4 \pm 6.7 \mathrm{~b}$ \\
Lactate $(\mathrm{mg} / \mathrm{dL})$ & $6.2 \pm 0.6 \mathrm{a}$ & $13.1 \pm 7.6 \mathrm{~b}$ & $7.3 \pm 0.9 \mathrm{a}$ & $7.6 \pm 1.2 \mathrm{a}$ \\
Insulin $(\mu \mathrm{UI} / \mathrm{mL})$ & $3.0 \pm 6.4 \mathrm{c}$ & $1.9 \pm 1.7 \mathrm{~b}$ & $1.4 \pm 1.3 \mathrm{a}$ & $1.7 \pm 1.4 \mathrm{~b}$ \\
Cortisol $(\mathrm{ng} / \mathrm{mL})$ & $48.5 \pm 7.9 \mathrm{a}$ & $42.6 \pm 19.7 \mathrm{a}$ & $62.9 \pm 21.8 \mathrm{a}$ & $40.3 \pm 17.0 \mathrm{a}$ \\
\hline
\end{tabular}

*Means within a row with no common letter differ by Tukey test $(\mathrm{p}<0.05)$. M1: at rest, before the beginning of the supplementation period; M2: immediately after eight hours of exercise, before the beginning of supplementation; M1S: at rest in individual stalls, after 30 days of supplementation; M2S: immediately after eight hours of exercise, after 30 days of supplementation.

According to Teixeira-Neto et al. (2007), the interpretation of cortisol measurements should be done with caution as results may be influenced by other facts despite physical exercise. According to reports of Irvine e Alexander
(1994) and Teixeira et al. (2008), the circadian rhythm of cortisol in horses has a peak in the morning and then constantly decreases until evening. So it's very important to evaluate values obtained before and after supplementation to 
check the influence of exercise. Therefore, Linden et al. (1990) and Marc et al. (2000) stated that the determination of plasma cortisol in horses is important to evaluate the stress induced by exercise. A slight variation in cortisol may be resulting from an adaptation of animals to physical exercise. This was described by Nogueira et al. (2002), who reported that cortisol, lactate and creatinine vary according to age and physical fitness. Nogueira's study (2002) also mentioned that a reduction in cortisol observed in Thoroughbred 2-3 year-old horses occurred due to better physical conditioning gained after a long period of training, when compared with 1-2 year-old horses that were not exercised and were kept on pasture. The same results were observed in the present experiment, suggesting adaptation to the imposed type of exercise.

There was a rise in plasma lactate when comparing M1 and M2. Gomide et al. (2006) argue that a significant increase in blood lactate occurs only after the end of a demanding physical activity with the main energy being produced anaerobically. The mean values of lactate found in M1 and M2 are similar to those of Persson (1983) who stated that the accumulation of lactate is related to the workload and the speed with which animals move during the exercise. This information is also confirmed by Delesalle et al. (2007) who stated that under normal conditions most lactate is produced by the erythrocytes, but during exercise or strenuous physical activity, the muscle produces large amounts of lactate due to the condition of insufficient oxygenation.

Linden et al. (1990) described a linear relationship between plasma lactate, glucose and speed of the exercise indicating that aerobic training can minimize hyperlactacidemia. According to Ferraz et al. (2008), the lactate threshold negatively correlates with the plasma glucose. The authors suggested these parameters as indicators of aerobic capacity in horses. Linden et al. (1990) reported that lactate production is much more related to the intensity of exercise than cortisol.

The variation of plasma glucose found in this study is similar to the findings of McKeever (2002) and McGowan (2008) who reported that increased plasma glucose is a common response to stress and is an extra source of energy that allows the animal to overcome the disturbances caused by the stressor, regardless of aerobic or anaerobic production of energy.

The results of serum insulin found in this study at the time before supplementation are consistent with those obtained by McKeever (2002) who stated that the horse suppresses insulin during exercise. As mentioned above, it allows the animal to increase gluconeogenesis to maintain blood glucose in appropriate concentrations during exercise and this happens due to the influence of cortisol and cathecolamines. According to Frank (2006), an animal that has high concentrations of plasma cortisol, can have a metabolic process known as insulin resistance (IR), during which there is a malfunction of insulin receptors in tissues and higher values of it will be seen. This was not observed in this study; where it was possible observe the suppression of insulin along with a lower level of cortisol after exercise.

Biochemical analysis after supplementation with chromium showed no significant difference between M1S and M2S in the plasma lactate and serum cortisol. However, significant difference between M1S when compared to M2S was observed for the determination of plasma glucose and serum insulin. Although there is no significant difference for determination of plasma glucose and serum insulin and cortisol between M2 and M2S, it was possible to observe a significant decrease in plasma lactate levels between the same moments. These results agree with those of Pagan et al. (1995) who suggested that chromium supplementation improves energy utilization, producing less lactate. They also showed a low cortisol level and lower lactate peak with chromium supplementation, which was also observed in the present study. Although Ott and Kivipelto (1999) claimed that supplementation of chromium alters the rate of glucose metabolism in horses, this was not observed in the present research because plasma glucose levels were similar between the two periods of analysis. Better energy utilization was probably due mobilization of other resources like fat and protein mobilization, but they were not evaluated. 


\section{CONCLUSIONS}

Chromium supplementation contributed to the decrease of the average values of lactate after the exercise, suggesting a better utilization of energy resources.

\section{REFERENCES}

BOOTH, F.W.; THOMASON, D.B. Molecular and cellular adaptation of muscle in response to exercise: perspectives of various models. Physiol. Rev., v.71, p.541-585, 1991.

DELESALLE, C.; DEWULF, J.; LEFEBVRE, R. et al. Determination of lactate concentrations in blood plasma and peritoneal fluid in horses with colic by an Accusport analyzer. J. Vet. Intern. Med., v.21, p.293-301, 2007.

FERRAZ， G.C.; D'ANGELIS， F.H.F.; TEIXEIRA-NETO, A.R. et al. Blood lactate reflects glucose responses in horses submitted to incremental exercise test. Arq. Bras. Med. Vet. Zootec., v.60, p.256-259, 2008.

FRANK, N. Insulin resistance in horses. In: ANNUAL CONVENTION OF THE AMERICAN ASSOCIATION OF EQUINE PRACTIONERS, 2006, San Antonio. Anais... San Antonio: AAEP, 2006. p.51-54.

FREESTONE, J.F.; WOLFSHEIMER, K.J.; KAMERLING, S.G. et al. Exercise induced hormonal and metabolic changes in Thoroughbred horses: effects of conditioning and acepromazine. Equine Vet. J., v.23, p.219-223, 1991.

GOMIDE, L.M.W.; MARTINS, C.B.; OROZCO, C.A.G. et al. Concentrações sangüíneas de lactato em equinos durante a prova de fundo do concurso completo de equitação. Cienc. Rural, v.36, p.509-513, 2006.

HARRIS, P.A.; HARRIS, R.C. Nutritional ergogenic aids in the horse - uses and abuses. In: CONFERENCE ON EQUINE SPORTS MEDICINE AND SCIENCE, 1998, Cordoba. Anais...Cordoba: The Netherlands Wageningen Pers, 1998. p.491-508.

IRVINE, C.H.G.; ALEXANDER, S.L. Factors affecting the circadian rhythm in plasma cortisol concentrations in the horse. Dom. Anim. Endocrinol., v.11, p.227-238, 1994.
KANEKO, J.J. Carbohydrate metabolism and its diseases. In: KANEKO, J.J.; HARVEY, J.W.; BRUSS, M.L. Clinical biochemistry of domestic animals. 4nd ed. San Diego: Academic, 1997. p.46-56.

LEAL, B.B.; FALEIROS, R.R.; ALVES, G.E.S. et al. Alterações no ritmo de cortisol em equinos de cavalaria militar relacionadas como maior ocorrência de cólica. In: SIMPÓSIO INTERNACIONAL DO CAVALO ATLETA, 3., 2007, Belo Horizonte. Anais... Belo Horizonte: UFMG, 2007. (CD-ROM).

LINDEN, A.; ART, T.; AMORY, H. et al. Comparison of the adrenocortical response to bothpharmacological and physiological stresses in sport horses. J. Vet. Med. A, v.37, p.601-604, 1990.

LINDNER, A. Use of blood biochemistry for positive performance diagnosis of sports horses in practice. Rev. Med. Vet., v.151, p.611-618, 2000.

MARC, M.; PARVIZI, N.; ELLENDORF, F. et al. Plasma cortisol anda ACTH concentrations in the warm blood horse in response to a standardized treadmill exercise test as physiological markers for evaluation of training status. J. Anim. Sci., v.78, p.1936-1946, 2000.

McGOWAN, C. Clinical pathology in the racing horse: the role of clinical pathology in assessing fitness and performance in the racehorse. Vet. Clin. N. Am.: Equine Pract., v.24, p.405-421, 2008.

McKEEVER, K.H. The endocrine system and the challenge of exercise. Vet. Clin. N. Am.: Equine Pract., v.18, p.321-353, 2002.

NUTRIENT Requirements of Horses. Washington DC: National Academy, 2007. 360p.

NOGUEIRA, G.P.; BARNABE, R.C.; BEDRAN DE CASTRO, J.C. et al. Serum cortisol, lactate and creatinina concentrations in Thoroughbred fillies of different ages and states of training. Braz. J. Vet. Res. Anim. Sci., v.39, p.54-57, 2002.

OTT, E.A.; KIVIPELTO, J. Influence of Chromium Tripicolinate on Growth and Glucose Metabolism in Yearling Horses. J. Anim. Sci., v.77, p.3022-3030, 1999. 
PAGAN, J.D.; JACKSON, S.G., DUREN, S.E. The effect of chromium supplementation on metabolic response to exercise in thoroughbred horses. In: EQUINE NUTRITION AND PHYSIOLOGY SOCIETY, 14., 1995, Ontario. Proceedings... Ontario: 1995. p.96-101.

PERSSON, S.G.B. Analysis of fitness and state of training: evaluation of exercise tolerance and fitness in the performance horse. In: SNOW, D.H.; PERSSON, S.G.B.; ROSE, R.J. Equine Exercise Physiology. Cambridge: Granata, 1983. p.470-486.

PRYCE, J.D. A modification of BarkerSummerson method for the determination of lactic acid. Analyst, v.94, p.1151-1152, 1969.

RADOSTITS, O.M.; MAYHEW, I.G.; HOUSTON, D.M. Exame clinico e diagnostico em Veterinária. Rio de Janeiro: GuanabaraKoogan, 2002. 591p.

REECE,W.O. Sistema endódrino. In: REECE, W.O. Anatomia functional e fisiologia dos animais domésticos. São Paulo: Roca, 2008. p.432-446.
SAEG - Sistema para Análises Estatísticas, Versão 9.1: Fundação Arthur Bernardes - UFV Viçosa, 2007.

SCHMID, M.; VON FORSTNER, D. Laboratory testing in the veterinary medicine and clinical monitoring. Mannheim: Boehringer, 1986. 253p.

TEIXEIRA, P.P.; MEIRINHOS, M.L.G.; PADUA, J.T. et al. Variações cíclicas do cortisol, triiodotironina (t3) e tiroxina (t4) no periparto de éguas da raça quarto de milha. Cienc. Anim. Bras., v.9, p.263-271, 2008.

TEIXEIRA-NETO, A.R.; FERRAZ, G.C.; D'ANGELIS, F.H.F. et al. Exercise intensity, but not electrolyte reposition, alters plasmatic cortisol and glucose levels of horses submitted to 30 and $60 \mathrm{~km}$ distance endurance rides. Cienc. Rural, v.37, p.740-743, 2007.

TRILK, J.L.; LINDNER, A.J.; GREENE, H.M. et al. A lactate-guided conditioning programme to improve endurance performance. Equine exercise physiology. Equine Vet. J., v.34, p.122125, 2002. 